\title{
Exiles in their region: pastoralist-farmer conflict and population displacements in North Central, Nigeria \\ Peter O. Mbah ${ }^{1}$, Kelechi C. Iwuamadi ${ }^{2}$, Ebele Udeoji ${ }^{3}$, Marcel Eze ${ }^{3} \&$ Christian C. Ezeibe ${ }^{1}$
}

\author{
${ }^{1}$ Department of Political Science, University of Nigeria, Nsukka, Enugu State Nigeria \\ ${ }^{2}$ Institute for Development Studies, University of Nigeria, Enugu, Enugu State Nigeria \\ ${ }^{3}$ Department of Political Science, National Open University of Nigeria, Abuja \\ Email: Christian.ezeibe@unn.edu.ng
}

\begin{abstract}
Background:Over the past two decades, pastoralist-farmer conflicts have become a pressing security challenge in Nigeria, especially in the North Central region. This study analyzed how pastoralist-farmer conflicts fuel population displacements in the North Central, Nigeria. It also assessed the livelihood of the internally displaced persons in the region.

Data Source and Methods: The study employed primary data comprising key informant interview of 37 stakeholders and field observations. It also utilized secondary data on pastoralist-farmer conflicts and population displacement largely sourced from Centre for Democracy and Development. We used simple percentage, frequency tables and content analysis of the qualitative data.

Results:The failure of the Nigerian state to manage pastoralist - farmer conflicts escalated the attacks and the forceful displacement it engendered. The displacements have worsened the humanitarian crisis as it has increased the number of people in immediate need of food, security, health, school, livelihood, shelter, protection, non food items, water, sanitation and hygiene.

Conclusion:The study concluded that building inclusive societies is relevant for de-escalating pastoralist-farmer conflicts, reducing population displacements, mitigating humanitarian crisis and achieving sustainable development goals in Nigeria and beyond.
\end{abstract}

Keywords: Pastoralist-farmer conflict, population displacements, North Central, Human Rights, Inclusion

\section{Introduction}

Population displacements refer to forceful of willful dislocation of a person or group of persons from their homes as a result of natural or man-made disasters. United Nations High Commissioner for Refugees (2019) noted that by the end of 2018, almost 70.8 million individuals were forcibly displaced worldwide as a result of persecution, conflict, violence, or human rights violations. While some displaced persons cross internal borders, the majority (4I.3 million people) are internally displaced. In subSaharan Africa, the numbers of internally displaced persons has been rising at an alarming rate in the last five decades. Significantly, most people are displaced in Africa due largely to violent conflict (Kellenberger, 2009; Oguonu and Ezeibe, 2014; Oyefara and Alabi, 2016). Herder-farmer conflicts in Africa have killed thousands of people, displaced tens of thousands from their communities; properties worth millions of dollars destroyed or looted, homes and crops burnt or destroyed, and livestock killed or rustled (Lenshie et al, 2020). Indeed, Africa is in the throes of an internal displacement crisis and this continues to increase the level of vulnerability across the globe (Getanda et al, 20l5)

In Nigeria, the number of internally displaced persons has increased from 470,500 in 2013 to 2.5 million in 2018 due to the escalation of Boko Haram in North East Nigeria from 2009 to 2019 (lbekwe, 2014; Nwangwu and Ezeibe, 2019; United Nations High Commissioner for Refugees,2019). As at 2018, Nigeria had the 4th highest number of internally displaced people in Africa, more than the war turn South Sudan and Sudan. Although vast majority of internally displaced people in Nigeria are in North East region (United Nations High Commissioner for Refugees, 2019), pastoralist-farmer conflicts have evolved from spontaneous reactions to deadly planned attacks resulting in more civilian deaths than Boko Haram insurgency in Nigeria (International Crisis Group, 2018). 
Despite the large-scale population displacements as a result of pastoralist-farmer conflicts in North Central region, narratives on conflicts and population displacements in Nigeria unduly focus on Boko Haram and the North East Nigeria (Adewale, 2016; Jacob, 2016; Eke, 2019; Ajodo-Adebanjoko, 2019; Ajayi, 2020). Scholars have related farmer-herder conflicts to security issues in Nigeria such as terrorism and secessionist movements (Lenshie et al. 2020; Chukwuma, 2020). Although studies have also linked population displacements in the North Central to long standing tensions between ethnic and linguistic groups, attacks by criminal groups, banditry, kidnapping, armed robbery and attacks by herdsmen (International Organization for Migration, 2019; 2020), empirical academic assessment of the nexus between herder-farmer conflicts and population displacements as well as the livelihood condition of displaced persons in North Central Nigeria have been neglected. This study analyzed how pastoralistfarmer conflicts fuel population internal displacements. It also assessed the condition of livelihood of internally displaced persons in North Central, Nigeria. Understanding herder-farmer conflicts, the population displacements they engender and the condition of livelihood of internally displaced persons in North Central Nigeria present opportunity for de-escalating the conflicts, reducing population displacements, mitigating humanitarian crisis and achieving sustainable development goals in Nigeria and beyond.

\section{Literature review and theoretical framework}

Although pastoralist-farmer conflicts are common across Africa Maiangwa (2017), it had intensified over the last decade in Nigeria, especially in the North Central and North West. There are remote and immediate causes of pastoralist-farmer conflicts in North Central region. While the remote causes include inept leadership, decline of state legitimacy and prevalence of armed non-state actors (Ezemenaka and Ekumaoko, 20l8), among the immediate causes are climatic changes induced droughts and desertification as well as loss of northern grazing lands to the expansion of human settlements (Kuna and Ibrahim, 20I5; International Crisis Group, 2017;Okigbo, 2018). Hence, land use change which prompts the pastoralists to push towards the North Central to the South with their livestock is one of the major causes of the conflicts (Muhammed et al, 2015; Kwaja and AdemolaAdelehin, 20/8). Other causes of pastoralist-farmer conflicts include destruction of crops by cattle and other property such as irrigational facilities, increasing rate of rural banditry and cattle rustling, retaliation for the destruction of livestock, political and ethnic strife intensified by the spread of illicit firearms, collapse of traditional conflict management mechanisms, increasing violence in the North East, inflammatory rhetoric by ethnic and religious leaders also contributes to the violence in the North Central region and antagonistic perceptions among farmers and herdsmen (Akov, 20l7; Ikeanyibe et al, 2018; Ezeibe and Ikeanyibe, 2017; Ajibo et al, 2018; International Crisis Group, 2017; 2018; Nnabuihe, 2019).

These conflicts have resulted in destruction of local communities, large-scale displacement of people; undermined food production as well as increased the rate of disabilities, hunger and malnutrition (Fajonyomi et al, 20l8; Okigbo, 2018; International Crisis Group, 2018; Chiluwa and Chiluwa, 2020). In 20018, pastoralist - farmer conflicts in the North Central intensified, killing at least I,600 people and displacing 300,000 people (Human Rights Watch, 2019). In Benue State alone, Ajibo et al. (2018, p. 157) remarked that "more than I,878 people were killed between 2014 and 2016 . Although international reports observed that population displacement is a major consequence of herder-farmer conflicts in Nigeria (Human Rights Watch, 2019; International Organization for Migration, 2019; 2020), there are dearth of empirical studies on how herder-farmer conflicts fuel population displacements and the condition of livelihood of internally displaced persons in North Central Nigeria. These spiraling conflicts and the displacement of people they engender also threaten the development progress made in recent decades (United Nations Department of Economic and Social Affairs, 20I5). Herder-farmer conflicts have also negatively impacted food security and national security (Uzobo and Akhuetie, 2018; Okoli and Ogayi, 2018; Fajonyomi et al, 2018; Chukwuma, 2020)

In response to these conflicts in order to ameliorate their impacts, the Nigerian governments created the grazing reserves in 1965, established the National Commission for Nomadic Education (NCNE) in 1989, used the armed forces to curb internal security, proposed cattle ranching system in 2018 and legislated anti-open grazing laws (Egbuta, 2018; Ortom, 2019). While studies have assessed the causes of herder-farmer conflicts. $M$ there is dearth of empirical academic studies on how the pastoralistfarmer conflicts fuel population displacement and the condition of livelihood of internally displaced persons in North Central Nigeria.

This study employed frustration-aggression theory as its framework of analysis. The theory posited that aggression is always a consequence of frustration and thus explains the cause of conflicts and violence 
(Dollard et. al., 1939). It stated that frustration causes aggression and when the source of the frustration cannot be challenged, the aggression gets displaced onto an innocent target (Miller, 194I; Whitley and Kite, 20I0). While aggression refers to an action with the intent to harm, and can be physical and nonphysical and manifest as conflicts and violence in societies, frustration is the condition which exists when a goal-response suffers interference. The failure to obtain a desired goal leads to aggressive behavior (Fox, 1954). However, aggression is not always the response to frustration. Rather a substitute response is displayed when aggressive response is not the strongest in the hierarchy. The four mediating factors which influence aggression are magnitude of frustration, aggression cues, arbitrariness of frustration, and cognitive and emotional processes (Berkowitz, 1989).

Magnitude of frustration is the intensity of blocking goal-directed behavior. Dollardet al. (1939) explains that being so close to one's goal and being neglected may be one act in an aggressive manner due to the excitement and expectation of receiving one's goal. Aggressive cues can identify the aggressive reaction resulting from a barrier to goal attainment. The aggressive and the neutral cues tend to enhance frustration which leads to aggression.

Arbitrariness of frustration, regarded as unexpected blocking of goals can lead to aggression. Certainly in the long run, expecting a however ultimately being prevented from it all of a sudden explains the arbitrariness of frustration-aggression actions or behavior. Cognitive and emotional processes emanation from frustration is most likely to lead to aggression when an individual or group's emotional experiences are interpreted as negative (Mbah, 20l4). Thus, the occurrence of aggressive behavior always presupposes the existence of frustration and contrariwise, that the existence of frustration always leads to some form of aggression.

Consequently, the blockage of the nomadic pastoralists by the sedentary local farmers from accessing forage and water for cattle leads to aggressive behavior such as violent conflict between the two production groups either to have access to land resources and water or to recover their land as well as their means of livelihood. Hence, "violent conflict is generated by the revolution of rising frustration due to revolution of rising expectations" (Mbah, 20|4:|3|). This is because the basic expectations are thwarted and each group experience profound sense of dissatisfaction and anger in the process of production. The two production groups are frustrated because both experience deprivation.
Access to land and water resources are central for the survival of both pastoralists and farmers. Meanwhile these resources are scarce. Competition for these scarce resources within the social environment engenders frustration and aggression between pastoralists and farmers. The invasion of farms and destruction of crops by cattle as well as increased cattle rustling in North Central Nigeria have worsened the aggressive tendencies of the two groups to survive. The failure of federal and state governments to resolve the conflicts have exacerbated it, thereby escalating other human security problems in the region such as internal population displacements and food crisis.

\section{Data and methods}

The study focus is the North Central geopolitical zone in Nigeria comprising Niger, Kogi, Kwara, Nassarawa, Benue and Plateau states. The population of the study is 15,562, 223 people in the North Central (National Bureau of Statistics, 2017). Three states including, Benue, Plateau and Nassarawa were purposively selected in the zone. Although the North Central zone have generally recorded the highest number of herder-farmer conflicts in Nigeria, these three states are the worst-hit by the conflicts with respect to the number of fatalities (International Organization for Migration, 2019; 2020). This study relied on both primary and secondary data. The primary data was draw from a sample of 37 stakeholders selected from two local governments in each state. Hence, data was collected from six local governments in the North Central that have witnessed major pastoralist-farmer conflicts and populations displacement. They include Agatu and Gwer East in Benue State; Riyon and BarkinLadi local governments in Plateau State; and Doma and Keana local governments in Nassarawa State. While 17 stakeholders selected from Benue State, 10 stakeholders each were selected from Plateau State and Nassarawa States. The criteria for selection of these stakeholders were cognate experience with pastoralist-farmer conflict and population displacement, availability and willingness to participate in the study.

Key informant interview (KII) was used to collect qualitative data from major stakeholders in the conflict-affected region. These stakeholders include village heads, leaders of Myetti Allah Cattle Breeders Association, Heads of Statistics in State Emergency Management Agency, and security personnel. The study also involved field observations and secondary literature on pastoralist-farmer conflicts. The KII was 
used to generate information on the dynamics of pastoralist-farmer conflicts and displacement patterns as well as the assessment of the condition of livelihood of the internally displaced persons. We also engaged in field observations in the selected local governments. The secondary data on herder-farmer conflicts and population displacements as well as the condition of livelihood of internally displaced persons in North Central Nigeria were sourced from Centre for Democracy and Development, International Organization for Migration and Amnesty International to supplement the primary data.

We basically adopted a variety of techniques and metaphors in analyzing the data. This is because there is no single overarching rule in analyzing qualitative data. We adopted descriptive statistics such as simple percentage and frequency tables for analysis. Data was collected between June and July, 2019 as well as a return visit in January, 2020 in order to validate the previously collected data. KII were conducted in Pigeon-English. They were transcribed to English languages, ordered and content-analyzed. The final manuscript was subjected to member check by the authors. This is relevant in order to enhance the credibility and validity of qualitative interpretations
(Koelsch, 2013; Ezeibe at al, 2017; Ezeibe et al, 2019).

\section{Results}

This section examined the dynamics of pastoralistfarmer conflicts and displacement patterns as well as assessment of the livelihood conditions of the internally displaced persons in North Central Nigeria.

Dynamics of pastoralist-farmer conflicts and displacement patterns

The numbers of attacks by the herdsmen in the North Central suggest that attention should focus on the region to understand the dynamics of the conflicts. From 2008 to 2018, while the average number of pastoralist attacks on farmers per year was 37.4 percent the average number of deaths per year was 437.8 (Centre for Democracy and Development, 2018). These averages in North Central Nigeria are far higher than the average pastoralist attacks and the number of death they engender in any other parts of the country. Table I shows the breakdown of herdsmen attacks in Nigeria by geopolitical zone from 2008 to 2018 .

Table I: Breakdown of Herdsmen Attacks by Region from March 2008 - March 2018

\begin{tabular}{|l|r|r|r|r|r|r|r|}
\hline Region & $\begin{array}{l}\text { No. of } \\
\text { attacks }\end{array}$ & $\begin{array}{l}\text { \% of } \\
\text { attacks }\end{array}$ & $\begin{array}{l}\text { No. of } \\
\text { deaths }\end{array}$ & $\begin{array}{l}\text { \% of } \\
\text { attacks }\end{array}$ & $\begin{array}{l}\text { No. of } \\
\text { Years }\end{array}$ & $\begin{array}{l}\text { Average } \\
\text { no. of } \\
\text { attacks per } \\
\text { year }\end{array}$ & $\begin{array}{l}\text { Average } \\
\text { no. of } \\
\text { deaths per } \\
\text { year }\end{array}$ \\
\hline South East & 33 & 5 & 103 & 1 & 10 & 3.3 & 10.3 \\
\hline South South & 77 & 11 & 246 & 3 & 10 & 7.7 & 24.6 \\
\hline South West & 44 & 6 & 84 & 1 & 10 & 4.4 & 8.4 \\
\hline North Central & 374 & 54 & 4378 & 58 & 10 & 37.4 & 437.8 \\
\hline North East & 88 & 13 & 1597 & 21 & 10 & 8.8 & 159.7 \\
\hline North West & 78 & 11 & 1081 & 14 & 10 & 7.8 & 108.1 \\
\hline Total & 694 & 100 & 7489 & 100 & 10 & 69.4 & 748.9 \\
\hline
\end{tabular}

Source: Centre for Democracy and Development, 2018

Table 2 shows total number of people killed in by herdsmen-farmer conflicts in different states in North Central Nigeria, from January 2016 to October 2018.

Table 2: Total number of people killed in Herdsmen-Farmer Conflicts, 2016- 2018

\begin{tabular}{|l|l|l|}
\hline S/N & States & Fatalities \\
\hline 1 & Benue & 726 \\
\hline 2 & Plateau & 472 \\
\hline 3 & Nasarawa & 196 \\
\hline 4 & Niger & 94 \\
\hline 5 & Kogi & 66 \\
\hline 6 & Kwara & 0 \\
\hline
\end{tabular}

Source: Amnesty International, 2018. 
Specifically, the village head of Ologbagiji in Agatu local government in Benue state in July 2019 revealed that "the herdsmen are always moving from place to place in search of greener pastures. They have over the years been involved in pasturing their livestock on peoples' farmlands and the people will definitely protest and resist the wanton destruction of their crops. This resistance frequently degenerates to conflict between the herdsmen and farmers in the state. The leader of Myetti Allah Cattle Breeders Association in Makurdi, Benue State in June 2019 reiterated that:

The herdsmen and farmers have lived peacefully in Benue valley for centuries. In fact most of the herdsmen are natives of Benue. The problem started with frequent killing and theft of our livestock. Nobody will keep quite when your only source of livelihood is destroyed with impunity. Meanwhile, it is not only herdsmen that revenge the destruction of their livestock, farmers have repeatedly revenge the destruction of their farms without compensation by killing herdsmen and their cattle in Benue and across Nigeria".

In collaboration to the above discourse, International Crises Group (2017) reported that herdsmen invaded two villages and killed some locals in Agatu local government in Benue state in retaliation for the killing of 112 cows. KII with the leader of Myetti Allah Cattle Breeders Association in Jos, Plateau State in January, 2020 averred that "the media and the general public often misinterpret the tendency for the herdsmen to defend themselves from criminals who steal our cattle. We do not attack local communities. We simply defend our cattle from criminals". Meanwhile, Higazi (2016,) observed that recovery of stolen cattle is often difficult. Rustlers are also armed and they attack herdsmen and security agencies. KII with one of the village heads in Riyon local government, Plateau State in June 2019, noted that Fulani herdsmen have dealt with Riyon people as a whole. They have involved in both direct and indirect killing of our people. Directly, they attack our villages and kill people in hundreds. Indirectly, they contributed to the deaths of our illustrious sons Senator Gyang Danton and Mr. Gyang Fulani, who died during a mass burial of people killed by herdsmen in 2012.

One major factor that contributes to the escalation of pastoralist-farmer conflicts in North Central region is the tendency for culprits to escape punishment. KII with one of the village heads in Gwer East local government in Benue State in January, 2020 revealed that "when the criminal herdsmen know that they always get away with crime, it emboldens them to do more. The herdsmen, who are largely Fulani became emboldened in 2015 after the emergence of President Buhari, who is a of Fulani ethnic origin. Herdsmen attacks became widespread as offenders are rarely arrested or punished. Meanwhile, we expect that the government should arrest, prosecute and punish arms bearing herdsmen.

Beyond the increasing rate of fatalities, the number of internally displaced persons as a result of pastoralist-farmer conflicts has escalated. International Organization for Migration (2019) observed that a total of 238,102 individuals and 41,105 households were displaced in the North Central and North West Zones by July 2019. Table 3 shows the number of individuals displaced by pastoralist-farmer conflicts in North Central Nigeria.

Table 3: Number of Displaced Individuals in North Central, Nigeria

\begin{tabular}{|l|l|}
\hline States & Number of Displaced Individuals \\
\hline Benue & 81,132 \\
\hline Nasarawa & 17,114 \\
\hline Plateau & 15,981 \\
\hline
\end{tabular}

Source: International Organization for Migration (2019)

Meanwhile, international reports on the number of internally displaced persons are marginal because they focus on people in camps and camp- like settlements. KIls with the Head of Statistic in State Emergency Management Agency in Benue Sate in June 2019argued that the number of internally displaced people in Benue between 2015 and 2019 is over 400,000. Similarly, KII with the Head of Research in State Emergency Management Agency in Plateau Sate in July 2019 revealed that the number of displaced people in the State is over 320,000.
Furthermore, the fear of military or police reprisal attacks on communities, where either of the conflicting parties have killed a soldier or police officer have been contributing to the internal displacement problems in North Central region. KII with one of the village heads in Agatu local government in Benue State in July 2019 further revealed that "most large- scale displacement of people in communities are caused by the fear of military or police retaliatory interventions. These security agencies often revenge the death of their colleagues in the valley by killing unarmed civilians, raping and maiming. Even if the herdsmen may have 
killed a security officer, the locals often bear the blunt". A Deputy Superintendent of Police, who pledged anonymity in Nassarawa State in January, 2020 noted that "security officers do not kill unarmed civilians as often alleged in the media. The problem is that criminals who live among the locals often attack the security agents and every security personnel is trained to for self- defence". Ibeanu (1998: 95) observed that:

We have tried to show in this paper that social insecurity mediated by state violence (in this case by the Nigerian state) gives rise to group conflicts which in turn leads to internal population displacement. Now the problem which requires urgent attention hinges on who should protect the rights of internally displaced people in Nigeria. Is it the Nigerian state? If we consider that the state is the primary cause of population displacement, we should not place too much weight on the Nigerian state's ability and willingness to provide the necessary protection, and guarantee security, for the affected population.

The failure of the state to provide security for farmers has contributed in eroding public trust. KII with one of the village heads in Keana local government in Nassarawa State in July 2019 showed that "local farming communities do not trust that the government security agencies can protect us. Who is supplying the herdsmen with weapons? Although I am not accusing the security agencies but god will punish whosoever that supplies the weapons to the herdsmen, especially the security agencies. We have confidence in our own vigilantes. The failure of government to provide for the needs of internally displaced people makes them to rely mostly on supports from host communities, individuals, religious bodies, and groups (Olanrewaju et al, 2019).

Livelihood conditions of the internally displaced persons in North Central Nigeria

The survey of internally displace persons in host communities, camps and camp- like settlements shows that they are in immediate need of food, security, health, school, livelihood, shelter, protection, non food items, water, sanitation and hygiene. Table 4 summarized the percentage of displaced people in immediate needs.

Table 4: The number of displaced people in immediate needs in North Central as at July, 2019

\begin{tabular}{|l|l|l|}
\hline S/N & Needs & Percentage \\
\hline $\mathbf{1}$ & Food & 72 \\
\hline $\mathbf{2}$ & Security & 62 \\
\hline $\mathbf{3}$ & Health & 59 \\
\hline $\mathbf{4}$ & School & 40 \\
\hline $\mathbf{5}$ & Livelihood & 79 \\
\hline $\mathbf{6}$ & Shelter & 82 \\
\hline $\mathbf{7}$ & Protection & 57 \\
\hline $\mathbf{8}$ & Water, Sanitation and Hygiene & 61 \\
\hline
\end{tabular}

Source: International Organization for Migration 2019.

Field observations and informal interactions with the internally displaced persons in North Central revealed that the food often arrived late and it is inadequate. Over 80 percent of the respondent believed the reason for late arrival of food and inadequate supply of food in camps is prevalence of corrupt officials involved in the management of the IDPs. International Organization for Migration (2019) reported that there was little food distributed in camps and camp-like settings in most camps in North Central region. Informal interaction with the internally displaced persons in North Central during field observation further revealed that IDPs obtained food by buying it with cash, labour or sex.

$\mathrm{KII}$ with one of the village heads in Agatu local government, Benue State in June 2019 maintained that "the most common health problem faced by internally displaced persons in host communities and camps was malaria due largely to low hygiene level and prevalence of mosquitoes. Another major health challenge was cholera and typhoid fever due to poor quality of cooking and drinking water". Field observations in Benue, Plateau and Nassarawa states, shows that 60 percent, 52 percent and 42 percent of internally displaced persons living in camps respectively are accommodated in schools, government buildings and emergency shelters. The number of out of school children has also increased in the North Central due to the conflicts. KII with one of the village heads in Doma local government in Nassarawa State in July 2019 noted that "insecurity has displaced most teachers, thereby increasing the number of out of school children in the state". KII with one of the village heads in Keana local government in Nassarawa State in July 2019 argued that "the concentration of people in camps and camp-like settlements make them easy targets for fresh attacks and re-victimization. This causes 
extreme depression and leads to suicide / suicide attempts in camps".

In addition to the threat of violence, internally displaced person, especially women and girls, who are the major victims of most conflicts (International Organization for Migration, 2019) face an additional threat of sexual violence as they perform their daily routine such as fetching of firewood and water. Notably, both criminals and security agencies harass and abuse women and girls in exchange for food and security. Some women also engage in survival sex, that is sex for food, security, shelter, protection and livelihood at the risk of sexually transmitted diseases and unwanted pregnancies (KII with one of the village heads in BarkinLadi local government, Plateau in July, 2019).

\section{Discussion}

Across North Central Nigeria, increased competition for diminishing resources has led to conflict between pastoralist communities and sedentary farmers and many of the pastoralists were forced to travel beyond traditional grazing lands in search of food and water (Wood, 2015; Lenshie et al, 2020). While conflictinduced forced migration is common in Africa, the situation in the North Central Nigeria is distinctive. First, it is a consequence of decades of armed conflict compounded by high prevalence of inter-communal conflict. Second, the displacement trajectory for displaced persons in the region proceeds through a sequence of pre-expulsion threats and vulnerability; expulsion; migration; protracted resettlement problems and the problem of returning to the community of origin (Adepoju, 20l I).

The effects of the conflict are enormous and disturbing. First, it has reawaken ethno- religious tensions within the country, widespread hatred and fear which have become endemic. Second, it has equally reawakened the dangerous minority nationalism geared towards violently eliminating perceived enemies (the Fulani); destruction of farms and the absence of farming in highly productive agricultural zones of the North Central Nigeria resulting in hunger and high food prices (Odah, 20I7).Significantly, pastoralist-famer conflict in North Central region, which is the second highest humanitarian challenge in Nigeria. Violent deaths as a result of clashes between herdsmen and farmers accounted for 68 percent of the total number of deaths and fuelling internal displacement across north-central Nigeria (International Crises Group, 2017). Often, the impact of population displacement on the people is very difficult to measure. It has also negative impact on countless host families and resident communities. While figures are notoriously hard to come by, no one would deny that Nigeria is the hard hit in terms of numbers of conflicts and of IDPs. The causes of displacement in Nigeria, as in other parts of Africa are of course manifold and complex. Aside natural disasters or developmentinduced displacement, the root causes of displacement are those that have triggered armed conflicts or situations of violence in the first instance. For example, poverty, the effects of climate change, scarcity of resources, political instability, and weak governance and justice systems have equally contributed for conflict-induced displacement.

In North Central, Nigeria, Awotokun et al (2020: 630) argued that:

Herders-farmers conflicts have resulted in the displacement of many persons from their ancestral homes, thus turning them into "exiles" and 'refugees' in their own country. The implication of internal displacement is evident at the micro and macro levels. At the micro-level, individuals and their families have suffered in diverse ways, namely, the indignity of relying on state hand-outs and charity for survival, traumatization arising from forceful dislocation from their ancestral environment, the destruction of their means of livelihood and consequent descent into poverty, and the depreciation in their overall quality of life. The combined effect has been the pauperization of these communities and their descent into the poverty trap. At the macro level, government policies enunciated to meet certain international benchmarks have been truncated, thus making their actualization impossible. Another distortion arising from internal displacement has been the diversion of resources that otherwise would have been channeled to developmental projects to cushioning the effects of humanitarian crises caused by internal displacement.

KII with one of the village head in Agatu local government in Benue State revealed that "over 70 percent of farmers in the community had to runway from the herders, who have used their cattle to destroy their farms. The conflicts have further impoverished our people and exposed them to hunger and diseases". Adisa and Adekunle (2010) rightly posited that farmers' loss of crop yield and income as a result of the herder-farmer conflicts contribute to prevalence of poverty among farmers. Collaboratively, the Governor of Benue State estimated that pastoralist-farmers conflicts have cost his state about $\$ 634$ million between 2012 and 2014 (International Crises Group, 2017). In addition to worsening poverty, KII with one of the village heads in BarkinLadi in Plateau State revealed that herder- 
farmer conflicts heighten unemployment, frustration, desperation, criminality and forceful displacement of people.

Although pastoralist-farmer conflict may have been undertaken by the parties primarily out of concern to promote ideological agenda and the welfare of one or the two groups as well as over access to resources (land and water) (Higazi, 20I6), the conflicts have created new grievances through the real and perceived violation of human rights by one or the two parties. Ajodo-Adebanjoko (2019) noted that farmer-herder conflicts undercut democratization, peace and development. The conflicts also undermine the protection and promotion of civil, political, economic and social rights (Ezeibe, 2016; Ajaero et al, 2018; Okoli and Ogayi, 2018). Hence, pastoralist-farmer conflicts create conditions akin to the Hobbesian state of nature in Nigeria, where life is nasty, poor, solitary brutish and short.

\section{Conclusion}

This study is an empirical assessment of how pastoralist- farmer conflicts fuel internal displacements as well as the livelihood conditions of the internally displaced persons in North Central, Nigeria. Using the frustration-aggression theory, the paper argued that the failure of the Nigerian state to manage pastoralist - farmer conflicts escalates the attacks and the forceful displacement the conflicts engender in North Central region. These forceful displacements of people in North Central have also increased the number of people in need of humanitarian assistance including food, security, health, school, livelihood, shelter, protection, non food items, water, sanitation and hygiene. Expectedly, women/ girls and children are mostly affected by these conflicts and the displacements they engender. Although both the state and civil society organizations frequently intervene to ameliorate the effects of these conflicts, the living conditions of displaced persons in camps and neighboring communities reflects how poorly the interventions are planned and implemented. The paper concluded that building peaceful, just and inclusive societies is relevant for de-escalating pastoralist-farmer conflicts, reducing population displacements, mitigating humanitarian crisis and achieving the sustainable development goals in Nigeria.

\section{Acknowledgements}

The authors are grateful to the participants in this study, especially, the village heads in North Central Nigeria. We also acknowledge the anonymous peer reviewers and the Editor of African Population Studies, Professor Clifford Odimegwu for their contributions to strengthen this paper.

\section{Disclosure statement}

No potential conflict of interest was reported by the authors.

\section{References}

Adepoju , A. (20II). Reflections on international migration and development in sub-Saharan Africa . African Population Studies, 25 (2), 298-319.

Adewale, S. (2016).Internally displaced persons and the challenges of survival in Abuja. African Security Review,25 (2), I76-192.

Adisa, R. S., \&Adekunle, O. A. (2010). FarmerHerdsmen Conflicts: A Factor Analysis of Socioeconomic Conflict Variables among Arable Crop Farmers in North Central Nigeria. Journal of Human Ecology, 30(I), I-9.

Ajaero C.K., Nzeadibe C. T and Ezeibe C.C. (2018). University of Nigeria Nsukka Research and Sustainable Development Goals.African Population Studies, 32 (2) Suppl. 4I09- 4I I 2.

Ajayi, T. F. (2020). Women, Internal Displacement and the Boko Haram Conflict: Broadening the Debate. African Security. Doi.org/ I0.1080/I9392206.2020.173 I I I0.

Ajibo, H. T., Onuoha, E. C., Obi-Keguna, C. N., Okafor, A. E. and Oluwole, I. O. (20I8). Dynamics of Farmers and Herdsmen Conflict in Nigeria: The Implication to Social Work Policy Intervention. International Journal of Humanities and Social Science, 8 (7), I57- 163.

Ajodo-Adebanjoko, A. (2019). Political economy and national security implications of resource-based conflicts in Nigeria. African Security Review, 28(I), 56-7I. doi:10.1080/10246029.2019.1655077.

Akov, E. T. (2017). Untangling the case of farmerherdsman clashes in the North Central region of Nigeria. African Security Review, 26 (3), 288-307.

Amnesty International (2018). Harvest of Death Three Years of Bloody Clashes between Farmers and Herders in Nigeria. Retrieved from https://www.amnesty.org/download/Documents/ AFR4495032018ENGLISH.PDF ( 6 December, 2019).

Awotokun, K. ,Nwozor, A. and Olanrewaju, J.S. (2020). Conflicts and the Retrogression of Sustainable Development: The Political Economy of Herders-Farmers' Conflicts in Nigeria .Humanities \& Social Sciences Reviews, 8 (I) 624633.

Berkowitz, L. (1989). Frustration-Aggression Hypothesis: Examination and Reformulation. Psychological Bulletin, I06 (I), 59-73.

Chiluwa, I and Chiluwa, I M (2020). 'Deadlier than Boko Haram': Representations of the Nigerian herder-farmer conflict in the local and foreign 
press. Media, War \& Conflict, I-22. DOI: 10.1 I77/1750635220902490

journals.sagepub.com/home/mw.

Chukwuma, K.H. (2020). Constructing the HerderFarmer Conflict as (in) Security in Nigeria. African Security, I 3 (I), 54-76.

Dollard, J., Doob, L. W, Miller, N. E., Mowrer, O. H., Sears, R. R. (1939). Frustration and Aggression. New Haven, CT, US: Yale University Press.

Duru, P. (2018). Farmers/herdsmen crisis: 80,450 children trapped in eight IDP camps across Benue https://www.vanguardngr.com/2018/03/farmersherdsmen-crisis-80450-children-trapped-eightidp-camps-across-benue/.

Egbuta, U. (20|8). Understanding the Herder-Farmer Conflict in Nigeria. Retrieved from https://www.accord.org.za/conflict-

trends/understanding-the-herder-farmer-conflictin-nigeria/( 13 December, 2018).

Eke, S. (2019). Nomad savage and herder-farmer conflicts in Nigeria: the (un)making of an ancient myth. Third World Quarterly, I-9. Doi: 10.1080/0।436597.2019.1702459

Ezeibe C, llo C, Oguonu C, Ali A, Abada I, Ezeibe E, Oguonu C, Abada F, lzueke E and Agbo H (2019). The impact of traffic sign deficit on road traffic accidents in Nigeria. International Journal of Injury Control and Safety Promotion, 26 (I), 3-I I.

Ezeibe C C and lkeanyibe O M (20I7).Ethnic Politics, Hate Speech, and Access to Political Power in Nigeria. Africa Today, 63, 4, 65-83.

Ezeibe C. C., T C. Nzeadibe, A N. Ali, C U. Udeogu, C F. Nwankwo , C Ogbodo (2017). Work on Wheels: Collective Organising of Motorcycle Taxis in Nigerian Cities. International Development Planning Review, 39 (3), 249-273.

Ezeibe C.C. (2016). ABC of Political Economy: A Beginner's Guide to Understanding the State and Economy. Nsukka: University of Nigeria Nsukka Press.

Ezemenaka, K. E. and Ekumaoko, Ch. E. (2018).Contextualising Fulani-Herdsmen Conflict in Nigeria. Central European Journal of International and Security Studies 12 (2), 30-55.

Fajonyomi, S. O., Fatile, J. O., Bello, O. W., Opusunju, M. I. and Adejuwon, D. K. (20/8). Farmers-Herdsmen Conflict and Food security in North Central Geo-Political Zone of Nigeria. International Journal of Advanced Studies in Economics and Public Sector Management, 6 (2), 43-62.

Fox, V. (1954). The Frustration-Aggression Hypothesis in Corrections. Quarterly Journal of the Florida Academy of Sciences, 17 (3), I 40-I 46.
Getanda, E.M., Papadopoulos, C and Evans H. (20I5).The mental health, quality of life and life satisfaction of internally displaced persons living in Nakuru County, Kenya. BMC Public Health, (20I5) I5 (755), I-9.

Higazi, A. (2016). Farmer-pastoralist conflicts on the Jos Plateau, central Nigeria: security responses of local vigilantes and the Nigerian state. Conflict, Security \& Development, 16(4), 365-385.

Human Rights Watch (2019). Nigeria Events of 2018: World Report. Retrieved from https://www.hrw.org/world-report/2019/countrychapters/nigeria (IIDecember, 2019).

Ibeanu, O. (1998). Exiles in their own Home: Internal Population Displacement in Nigeria. African Journal of Political Science, 3 (2), 80-97.

lbekwe, N. (20l4). Nigeria sets new record; now has Africa's highest number of displaced persons. Retrieved from https://www.premiumtimesng.com/news//6I344nigeria-sets-new-record-now-has-africas-highestnumber-of-displaced-persons. html (II June 20I4). Ikeanyibe O. M., Ezeibe C. C., Mbah P. O. and Nwangwu C. (2018). Political Campaign and Democratisation: Interrogating the Use of Hate Speech in the 20II and 2015 General Elections in Nigeria. Journal of Language and Politics, 17 (I), 92-117.

Internal Displaced Monitoring Centre (2018). Patterns of Displacement. Retrieved from http://www.internal-

displacement.org/countries/nigeria (7 December, 2019)

International Crisis Group (2017) Herders against Farmers: Nigeria's Expanding Deadly Conflict. Retrieved from https://www.crisisgroup.org/africa/westafrica/nigeria/252-herders-against-farmersnigerias-expanding-deadly-conflict (19 September, 2017)

International Crisis Group (20/8) Stopping Nigeria's Spiralling Farmer-Herder Violence. Retrieved from https://www.crisisgroup.org/africa/westafrica/nigeria/262-stopping-nigerias-spirallingfarmer-herder-violence (26July, 2018).

International Organization for Migration (2019) Flash Report: Displacement in North Central and North West States. Retrieved from: https://reliefweb.int/sites/reliefweb.int/files/resour ces/Nigeria\%20-

\%20Displacement\%20in\%20North\%20Central $\% 20$ and\%20North\%20West\%20States\%20Flash \%20Report\%20\%20\%2826\%20July\%202019\% 29.pdf (accessed: 26 July 2019 
International Organization for Migration (2020) Flash Report \# 17: Population Displacement North West/North Central Nigeria. Retrieved from: https://reliefweb.int/report/nigeria/iom-nigeriaflash-report-17-population-displacement-northwestnorth-central-nigeria (accessed: 20 September 2020)

Jacob, J.U. (20/6). Narratives of Displacement: Conversations with Boko Haram Displaced Persons in Northeast Nigeria. Contemporary French and Francophone Studies, 20 (2 ) 176190.

Kellenberger, J. (2009). Root causes and prevention of internal displacement: The ICRC perspective. Retrieved from https://www.icrc.org/en/doc/resources/document s/statement/displacement-statement-231009.htm (23 February, 2009).

Koelsch, L.E. (20I3). Reconceptualizing the Member Check Interview. International Journal of Qualitative Methods, 12 (I), I68-I 79.

Kuna, M. and Ibrahim, J. (2015). (eds) Rural Banditry and Conflicts in Northern Nigeria. Abuja: Centre for Democracy and Development.

Kwaja, C. and Ademola-Adelehin, B. (2018). Responses to Conflicts between Farmers and herders in the Middle Belt of Nigeria: Mapping Past Efforts and Opportunities for Violence Prevention. Retrieved from https://www.sfcg.org/wpcontent/uploads/2018/03/Responses-to-Conflictsbetween-Farmers-and-Herders-in-the-MiddleBelt-FINAL.pdf (30 January, 2018).

Lenshie, N, E ,Okengwu, K., Ogbonna, C.N and Ezeibe, C (2020) Desertification, Migration and Herder-farmer Conflicts in Nigeria: Rethinking the ungoverned spaces thesis. Small Wars \& Insurgencies.

DOI: I0.1080/09592318.2020.1811602

Maiangwa, B. (2017). Conflicting Indigeneity and Farmer-Herder Conflicts in Postcolonial Africa. Peace Review, 29(3), 282-288.

Miller, N. E. (194I). The frustration-aggression hypothesis. Psychological Review, 48 (4) 337-366.

Muhammed, I. ,Ismaila, A. and Bibi, U. (20I5). An assessment of farmer-pastoralist conflict in Nigeria using GIS. International Journal of Engineering Science Invention, 4(7), 23-33.

National Bureau of Statistics (2017). Demographic Statistics Bulletin: 2017. Abuja. Nigeria: National Bureau of Statistics.

Nnabuihe, O. (2019). Horizontal inequalities and ethno-religious conflicts in Jos metropolis, NorthCentral Nigeria. Canadian Journal of African Studies, 53 (2), 273-294.
Nwangwu C. and Ezeibe C. (2019) Femininity is not Inferiority: Women-led Civil Society Organizations and 'countering violent extremism' in Nigeria. International Feminist Journal of Politics, 2I (2), 168-193.

Odah, A. (2017). Herdsmen Against Farmers in North Central Nigeria: Implications for Peace and Nation Building http://www.rosalux.sn/wpcontent/uploads/2016/03/News_Actualit\%C3\%A 9s-072017.pdf.

Oguonu C. \& Ezeibe C. C (20I4) African Union and Conflict Resolution in Africa. Mediterranean Journal of Social Sciences, 5 (2), 325-332.

Okigbo, P. O. (20|8). An Initiative to Resolve the Herdsmen-Farmers Conflict in Nigeria, Abuja: Nextier SPD.

Okoli, A. and Ogayi, C. (2018). Herdsmen militancy and humanitarian crisis in Nigeria: A theoretical briefing. African Security Review , 27 (2), I29-I 43.

Olanrewaju, F., Olanrewaju, A. Omotoso, F., Alabi, J Amoo, E. Loromeke, E. and Ajay, L. (2019). Insurgency and the Invisible Displaced Population in Nigeria: A Situational Analysis. Sage Open, I12. DOI: I0.1 I 77/2158244019846207.

Ortom, S. (2019). The challenges of mitigating herdsmen attacks on people of Nigeria: Lessons from Benue State. Being a paper presented by the Executive Governor of Benue State at the Princess Alexandra Auditorium, University of Nigeria, Nsukka.

Oyefara J .L and Alabi, B.O. (2016). Socio-economic Consequences of Development-induced Internal Displacement and the Coping Strategies of Female Victims in Lagos Nigeria: An ethno-demographic Study. African Population Studies, 30 (2) (Supp.), 2520-2532.

Shultz, J. M. et al (20|4). Internally Displaced "Victims of Armed Conflict" in Colombia: The Trajectory and Trauma Signature of Forced Migration available https://www.ncbi.nlm.nih.gov/pmc/articles/PMC4 $765495 /$.

United Nations Department of Economic and Social Affairs (2015).Transforming our world: The 2030 Agenda for Sustainable Development.Sustainable Development Knowledge Platform.Retrieved fromhttps://sustainabledevelopment.un.org/conte nt/documents/789I Transforming\%200ur\%20Wo rld.pdf(20 August 2015).

United Nations High Commissioner for Refugees (2019). Global Trends: Forced Displacements in 2018. Geneva, Switzerland: United Nations High Commissioner for Refugees.

United Nations Office for the Coordination of Humanitarian Assistance (2014) Guiding Principles on Internal Displacement. 
https://docs.unocha.org/sites/dms/Documents/Gui dingPrinciplesDispl.pdf

Uzobo, E and Akhuetie, R. (20/8).Food Security and Health Challenges among Internally Displaced Persons in Nigeria .Nigerian Journal of Sociology and Anthropology, I6 (I), 47-7I.

Whitley, B. and Kite, M (2010). The Psychology of Prejudice and Discrimination (2nd ed.). Belmont, CA: Cengage Learning.
Wood, T. (2015). Human vs 'natural' causes of displacement: the relationship between conflict and disaster as drivers of movement https://www.nanseninitiative.org/staffmember/hu man-vs-natural-causes-of-displacement-therelationship-between-conflict-and-disaster-asdrivers-of-movement/ (16 October, 2016). 